\title{
MENELISIK SEJARAH DAN KEBERAGAMAN CORAK PENAFSIRAN AL-QUR'AN
}

\author{
Kusroni, \\ STAI Al Fithrah, Surabaya \\ Email : kusroni87̄ive.com
}

\begin{abstract}
Abstrak:
Tafsir al-Qur'an merupakan usaha yang dilakukan oleh manusia sesuai kemampuan dan kompetensinya dalam memahami makna kalam Allah. Pada masa Nabi yang notabene beliau adalah mufasir tunggal, belum muncul keberagaman corak dalam penafsiran, karena sumber penafsiran hanya satu yaitu Nabi. Hal ini berbeda dengan masa di mana umat Islam telah menyebar di berbagai wilayah yang dibarengi dengan terjadinya perkembangan ilmu pengetahuan dan berkembangnya berbagai aliran madhhab dan pemikiran. Perkembangan ilmu pengetahuan serta lahirnya berbagai aliran madhhab juga memberikan dampak pada keberagaman corak penafsiran al-Qur'an. Tulisan ini menelisik akar sejarah dan keberagaman corak penafsiran. Hasil analisis literatur menunjukkan bahwa sejarah kemunculan dan keberagaman corak penafsiran lahir bersamaan dengan berkembangnya ilmu pengetahuan dan munculnya berbagai aliran madhhab dalam Islam. Perkembangan ilmu pengetahuan melahirkan berbagai corak penafsiran seperti corak lughawi, fiqhi, falsafi, süfi, 'ilmìi, dan lain-lain. Sedangkan lahirnya berbagai aliran madhhab memunculkan corak sunnì, shì 'î, mu'tazili dan lain-lain sesuai dengan ideologi yang dianut oleh mufasir.
\end{abstract}

Kata kunci : Corak tafsir, perkembangan tafsir, keberagaman corak tafsir

\section{Abstract:}

Tafsir al-Qur'an is an effort made by humans according to ability and competence in understanding the meaning of the word of Allah. At the time of the Prophet Muhammad who is a single mufasir, has not emerged the diversity of style in interpretation, because the source of interpretation is only one that is the Prophet. This is different with the period in which Muslims have spread in various regions accompanied by the development of science and the development of various thought and madhhab. 
Menelisik sejarah dan keberagaman corak

penafsiran al-Qur'an

The development of science and the birth of various madhhab also give an impact on the diversity of the style of the Qur'an interpretation. This paper examines the historical roots and diversity of interpretive styles. The results of the literature analysis show that the history of the emergence and diversity of interpretive styles was born along with the development of science and the emergence of various madhhab in Islam. The development of science gave birth to various shades of interpretation such as lughawi, fiqhi, philosophical, sufi, and ilmi, and others. While the birth of various madhhab raises the style of sunni, syi'i, mu'tazili and others in accordance with the ideology adopted by the mufasir.

Keywords: Style of interpretation, development of interpretation, diversity of tafsir style.

\section{Prolog}

Kemajuan dalam bidang pemikiran sangat berpengaruh terhadap perkembangan keilmuan dan pengetahuan, baik ilmu eksak maupun ilmu religi atau agama. Ilmu tafsir dalam kapasitasnya sebagai mubayyin atau penjelas terhadap teks atau nas suci al-Qur'an tidak bisa lepas dari kemajuan perkembangan sebagaimana telah disebut di atas.

Banyak sekali perkembangan dan kemajuan yang terjadi terhadap ilmu tafsir, mulai dari corak, metode, pedekatan maupun teori pemaknaan. Tulisan ini akan berusaha menelisik akar sejarah dan keberagaman corak dalam penafsiran al-Qur'an. Tulisan ini diharapkan bisa menjadi bahan rujukan dalam kajian tafsir al-Qur'an dan sekaligus memberikan gambaran yang jelas mengenai keberagaman dalam khazanah tafsir al-Qur'an. Tulisan ini menggunakan metode kualitatif dengan analisis data kepustakaan (library research). Data yang dikaji dan dianalisis dalam penelitian ini adalah kitab-kitab dan buku tafsir, metodologi tafsir, dan sejarah tafsir.

Pertanyaan yang didiskusikan dan berusaha untuk dijawab dalam tulisan ini adalah, (1) apa yang dimaksud dengan corak tafsir? (2) Bagaimana akar sejarah munculnya keberagaman corak penafsiran alQur'an? (3) Corak apa saja yang ada dan berkembang dalam penafsiran alQur'an?

\section{Pengertian Corak Tafsir}

Dalam kamus bahasa Indonesia kata corak mempunyai beberapa makna. Di antaranya corak berarti bunga atau gambar (ada yang berwarna 
Menelisik sejarah dan keberagaman corak penafsiran al-Qur'an

-warna) pada kain (tenunan, anyaman), juga bermakna berjenis-jenis warna pada warna dasar, juga berarti sifat (faham, macam, bentuk) tertentu. ${ }^{1}$ Kata corak dalam literatur sejarah tafsir, biasanya digunakan sebagai terjemahan dari kata al-laun, bahasa Arab yang berarti warna. Istilah ini pula digunakan Husain al-Dhahabì dalam kitabnya al-Tafsir waal-Mufassirūn. Berikut potongan ulasan beliau ( وعن ألو ان التفسير فى هذا العصر . الحديث....) (Tentang corak-corak penafsiran di abad modern ini).

Corak tafsir diartikan sebagai kecenderungan keahlian atau spesifikasi yang dimiliki oleh seorang mufasir. Hal ini bisa dilatarbelakangi oleh pendidikan, lingkungan maupun akidahnya. ${ }^{2}$ Oleh sebab itu, bila mufasir adalah seorang ahli bahasa, maka dia menafsirkan ayat-ayat al-Qur'an menggunakan pendekatan analisa kebahasaan, atau biasa dikenal dengan corak lughawi. Bila mufasir adalah seorang pakar dalam bidang ilmu pengetahuan (sains), maka kecenderungan penafsirannya adalah lebih menggunakan pendekatan ilmiah atau biasa dikenal denga istilah corak 'ilmî, dan begitu seterusnya. Akan tetapi, kesimpulan di atas bukan berarti memberikan pemahaman bahwa mufasir hanya memiliki satu keahlian dalam cabang ilmu saja, karena dalam menafsirkan al-Qur'an dibutuhkan seabrek perangkat dan persyaratan akademis maupun metodologis.

Sedangkan kata tafsir merupakan masdar dari kata fassarayufassiru-tafsiran, yang dalam kamus al-Munawwir bermakna tafsiran, interpretsi, penjelasan, komentar, dan keterangan. ${ }^{3}$ Arti tafsir itu sendiri menurut bahasa (lughah) Arab adalah التبيين dan الإيضاح (menjelaskan, menerangkan). ${ }^{4}$

Dalam kitab Lisān al-'Arāb dijelaskan bahwa kata tafsir diambil dari kata al-fasru yang berarti menjelaskan dan menyingkap sesuatu yang tertutup. Kata al-tafsir juga bermakna menyingkap maksud sesuatu yang sulit. $^{5}$

Sedangkan tafsir menurut istilah adalah:

\footnotetext{
1 Tim Penyusun Kamus Pusat Bahasa, Kamus Besar Bahasa Indonesia, (Jakarta: Balai Pustaka, 2005), 220.

${ }^{2}$ Anshori LAL, Tafsir bi al-Ra'yi, Menafsirkan al-Qur'an dengan Ijtihad, (Jakarta, Gaung Persada Press, 2010), 88

3 Ahmad Warson Munawwir, Kamus Al-Munawwir, (Yogyakarta: Pustaka Progressif, 1997), 1068

${ }^{4}$ Muhammad Husein al-Dhahabi, al-Tafsir wa al-Mufassirūn, (Maktabah Mus'ab ibn Umar al-Islāmiyah, 2004), Vol.I, 12

${ }^{5}$ Muhammad bin Mukram bin Manzhūr al-Afriqìi, Lisān al-'Arab. (Beirut: Dār Șādir, 1412 H), Vol.V,55.
} 
Menelisik sejarah dan keberagaman corak penafsiran al-Qur'an

التفسير علم يعرف به فهم كتاب الله المنزل على نبيه محمد صلى الله عليه وسلم وبيان معانيه

و واستخر اج أحكامه وحكمه.

"Tafsir adalah Ilmu untuk memahami Kitab Allah yang diturunkan kepada Nabi Muhammad SAW. untuk menjelaskan makna-maknanya, menyimpulkan hukum-hukumnya dan hikmah-hikmahnya". ${ }^{6}$

Dari penjelasan dua kata di atas, yakni corak dan tafsir, maka bisa ditarik pemahaman bahwa corak tafsir adalah bentuk kecenderungan dalam menafsirkan al-Qur'an yang dilatari oleh kapasitas yang dimiliki mufasir.

\section{Kemunculan dan Keberagaman Corak Penafsiran al-Qur'an}

al-Qur'an memang sangat terbuka untuk ditafsirkan (multi interpretable), dan masing-masing mufasir ketika menafsirkan al-Qur'an biasanya juga dipengaruhi oleh kondisi sosio-kultural di mana ia tinggal, bahkan situasi politik yang melingkupinya juga berpengaruh baginya. Di samping itu, ada kecenderungan dalam diri seorang mufasir untuk memahami al-Qur'an sesuai dengan disiplin ilmu yang ia tekuni, sehingga meskipun objek kajiannya tunggal (yaitu teks al-Qur'an), namun hasil penafsiran al-Qur'an tidaklah tunggal, melainkan plural. Oleh karenanya, munculnya corak-corak penafsiran tidak dapat dihindari dalam sejarah pemikiran umat Islam. ${ }^{7}$

Keberagaman corak penafsiran merupakan hal positif yang menunjukkan akan kekayaan khazanah pemikiran umat Islam yang digali dari al-Qur'an. Ini artinya al-Qur'an telah memberikan andil yang cukup besar dan merestui bagi tumbuh suburnya pluralitas dalam penafsiran itu sendiri. Karena hampir dalam setiap lini kehidupan, termasuk dalam pemikiran fiqh, kalam, tasawuf, dan tafsir terdapat aliran atau madhhab yang bervariasi. ${ }^{8}$

Dalam menyikapi keberagaman corak penafsiran di atas, menurut Abdul Mustaqim, ada beberapa sikap yang bisa dan mesti diambil. Pertama: kritis dalam melihat produk-produk tafsir tersebut, apakah ada hidden interest dibalik penafsirannya? Apakah ada penyimpangan dan apakah penafsirannya didukung oleh argumentasi yang kuat? Kedua: jika

\footnotetext{
${ }^{6}$ Al-Zarkāshì, “Al-Burhān fì Ulūm al-Qur'ān”, (Dār al-Ahyā al-Kutub al-Arabiyah, Jilid I cet I, 1376 H-1957 M), 13

${ }^{7}$ Abdul Mustaqim, Pergeseran Epistemologi Tafsir, (Jakarta: Pustaka Pelajar, 2008), 5960 .

${ }^{8}$ Ibid.
} 
memang argumen-argumen tersebut kuat, maka kita harus menghormati pendapat tersebut, meskipun kita tidak harus mengikuti. ${ }^{9}$

Dari kenyataan di atas, bisa ditarik pemahaman bahwa, corak tafsir adalah nuansa atau sifat khusus yang mewarnai sebuah penafsiran dan merupakan salah satu bentuk ekspresi intelektual seseorang mufasir tatkala ia menjelaskan maksud-maksud ayat al-Qur'an. Artinya bahwa kecenderungan pemikiran atau ide tertentu mendominasi sebuah karya tafsir.

Pada abad pertengahan, berbagai corak ideologi penafsiran mulai muncul, yakni pada masa akhir dinasti Umayyah dan awal dinasti 'Abbāsiyah. Momentum ini menemukan masa emasnya terutama pada masa pemerintahan khalifah kelima dinasti 'Abbāsiyah, yaitu Harun alRashid (785-809 M). Sang khalifah memberikan perhatian khusus terhadap perkembangan ilmu pengetahuan. Tradisi ini kemudian dilanjutkan oleh khalifah berikutnya yaitu al-Makmūn (813-830 M). Dunia Islam pada saat itu bisa jadi merupakan puncak kemajuan dalam peta pemikiran dan pendidikan serta peradaban, masa ini dikenal dengan zaman keemasan (the golden age). ${ }^{10}$

Di sisi lain, ilmu yang berkembang di tubuh umat Islam selama periode abad pertengahan yang bersentuhan langsung dengan keislaman adalah ilmu fiqh, ilmu kalam, ilmu tasawuf, ilmu bahasa, sastra dan filsafat. Karena banyaknya orang yang berminat besar dalam studi setiap disiplin ilmu itu yang menggunakan basis pengetahuanya sebagai kerangka dalam memahami al-Qur'an, serta mencari dasar yang melegitimasi teori-teorinya dari al-Qur'an, maka muncullah kemudian

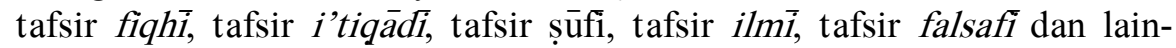
lain. $^{11}$

Jadi, corak tafsir adalah nuansa atau sifat khusus yang mewarnai sebuah penafsiran dan merupakan salah satu bentuk ekspresi intelektual seseorang mufasir, ketika ia menjelaskan maksud-maksud ayat al-Qur'an. Artinya bahwa kecenderungan pemikiran atau ide tertentu mendominasi sebuah karya tafsir. Kata kuncinya adalah terletak pada dominan atau tidaknya sebuah pemikiran atau ide tersebut. Kecenderungan inilah yang kemudian muncul ke permukaan pada periode abad pertengahan. ${ }^{12}$

Kitab-kitab tafsir yang berhasil dikaryakan oleh sarjana-sarjana muslim pada masa itu antara lain seperti tafsir Jämi' al-Bayān 'an Ta'wìl

\footnotetext{
${ }^{9}$ Ibid.

${ }^{10}$ Abdul Mustaqim, Pergeseran Epistemologi Tafsir, (Jakarta, Pustaka Pelajar, 2008), 61.

${ }_{11}^{1}$ Ahmad Izzan, Metodologi Ilmu Tafsir, (Bandung: Tafakur,2009), 20.

${ }^{12}$ Mustaqim, Pergeseran Epistemologi Tafsir, (Jakarta, Pustaka Pelajar, 2008), 61.
} 
Menelisik sejarah dan keberagaman corak

penafsiran al-Qur'an

al-Āyi al-Qur'ān karya Ibnu Jarìr al-Ṭabarì (w: 923 M), al-Kashshāf karya Zamakhshari (w:1144 M) yang bercorak ideologi Mu'tazilah, kemudian Mafătih al-Ghaīb karya Fakhr al-Dīn al-Rāzi (w:1209 M) dengan corak teologi sunni, dan Tafsir al-Jalälain karya al-Mahalli (w:1459 M) bersama al-Suyūtị (w:1505 M) dengan corak lughawī.

Muhammad Husein al-Dhahabi mengatakan bahwa setiap orang yang membaca kitab-kitab tafsir dengan berbagai macam corak (alwān)nya tidak akan memiki keraguan bahwa segala hal yang berkaitan dengan kajian-kajian tafsir tersebut telah dibahas dan dirintis oleh mufasirmufasir terdahulu (al-Aqdamūn $).{ }^{13}$

Adapun corak-corak tafsir yang berkembang dan populer hingga masa modern ini adalah sebagai berikut:

\section{Corak Lughawi}

Corak lughawi adalah penafsiran yang dilakukan dengan kecenderungan atau pendekatan melalui analisa kebahasaan. Tafsir model seperti ini biasanya banyak diwarnai dengan kupasan kata per kata ( $t a h\lceil i l$ al-lafz), mulai dari asal dan bentuk kosa kata (mufradāt), sampai pada kajian terkait gramatika (ilmu alat), seperti tinjauan aspek nahwu, sarf, kemudian dilanjutkan dengan qirä'at. Tak jarang para mufasir juga mencantumkan bait-bait syair Arab sebagai landasan dan acuan. ${ }^{14}$

Oleh karena itu, seseorang yang ingin menafsirkan al-Qur'an dengan pendekatan bahasa harus mengetahui bahasa yang digunakan alQur'an yaitu bahasa Arab dengan segala seluk-beluknya, baik yang terkait dengan nahwu, balaghah dan sastranya. Dengan mengetahui bahasa alQur'an, seorang mufasir akan mudah untuk melacak dan mengetahui makna dan susunan kalimat-kalimat al-Qur'an sehingga akan mampu mengungkap makna di balik kalimat tersebut. Bahkan Ahmad Shurbasi menempatkan ilmu bahasa dan yang terkait (nahwu, sarf, etimologi, balāghah dan qirā'at) sebagai syarat utama bagi seorang mufasir. ${ }^{15} \mathrm{Di}$ sinilah, urgensi bahasa akan sangat tampak dalam penafsirkan al-Qur'an.

Di antara kitab tafsir yang menekankan aspek bahasa atau lughah adalah Tafsir al-Jalālain karya bersama antara al-Suyūṭi dan al-Mahalli, Mafătị̣ al-Ghaib karya Fakhruddin al-Rāzi, dan lain-lain.

\footnotetext{
13 Muhammad Husein al-Dzahabī, al-Tafsìir wa al-Mufassirūn, (Maktabah Mus'ab ibn Umar al-Islāmiyah, 2004), 194.

${ }^{14}$ Abdul Mustaqim, Pergeseran Epistemologi Tafsir, (Jakarta, Pustaka Pelajar, 2008), 87 89

15 Ahmad Shurbasi, Sejarah Perkembangan Tafsir al-Qur'an al-Karim, (Jakarta: Kalam Mulia, Cet. I, 1999), 31
} 
Menelisik sejarah dan keberagaman corak penafsiran al-Qur'an

Di bawah ini merupakan contoh penafsiran corak lughawii:

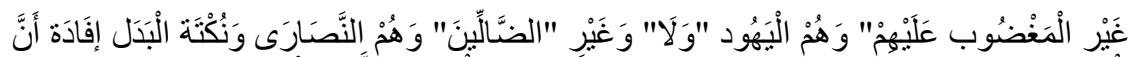

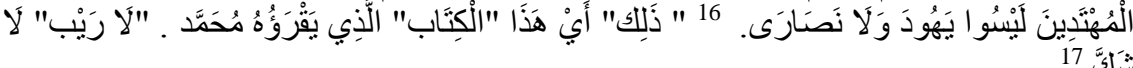

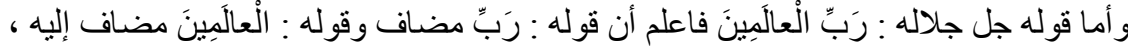

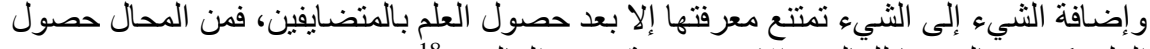

$$
\begin{aligned}
& \text { العلم بكونه تعالى ربا للعالمين إلا بعد معرفة ربع الاب و العالمين. } 18
\end{aligned}
$$

\section{Corak Filsafat}

Di antara pemicu munculnya keragaman penafsiran adalah perkembangan kebudayaan dan pengetahuan umat Islam. Bersamaan dengan itu pada masa Khilăfah 'Abbāsiyah banyak digalakkan penerjemahan buku-buku asing ke dalam bahasa Arab. Di antara bukubuku yang diterjemahkan tersebut adalah buku-buku filsafat, yang pada gilirannya dikonsumsi oleh umat Islam.

Contoh penafsiran corak filsafat sebagaimana ditulis oleh alDhahabi adalah sebagai berikut:

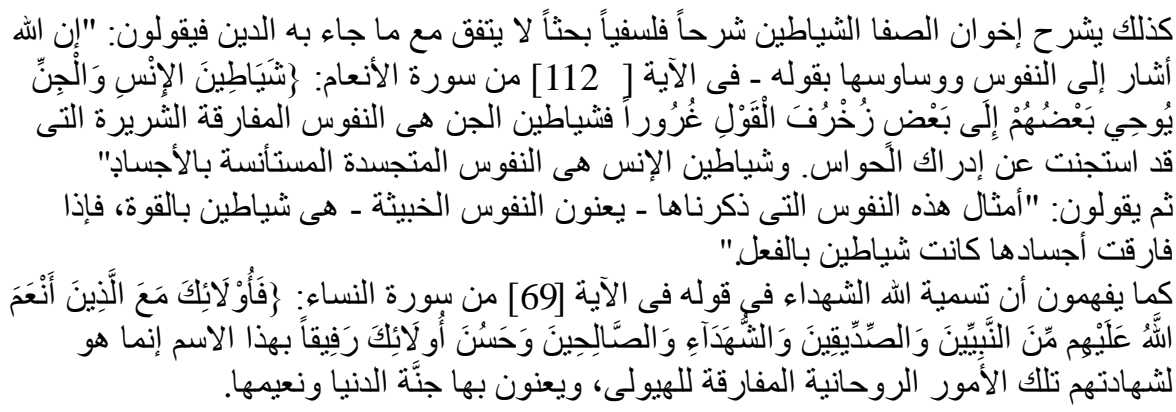

\section{Corak Ilmiah ( $i l m \overline{1}$ )}

Corak ini muncul akibat kemajuan ilmu pengetahuan dan teknologi. Oleh karena itu muncul usaha-usaha penafsiran al-Qur'an yang sejalan dengan perkembangan ilmu yang terjadi.

Di samping itu, al-Qur'an juga mendorong perkembangan ilmu pengetahuan. al-Qur'an mendorong umat Islam untuk memerdekakan akal dari belenggu keraguan, melepaskan belenggu-belenggu berfikir, dan mendorongnya untuk mengamati fenomena alam. Allah ta'ala telah mendorong kita untuk mengamati ayat-ayat kauniyah, di samping ayat-

\footnotetext{
${ }^{16}$ Al-Mahalli, al-Suyūțī, Tafsir al-Jalālain,tp.,tt,2

${ }^{17}$ Ibid.

${ }^{18}$ Al-Rāzi, Mafătih al-Ghaib, (Beirut: Dār Ihyā' al-Turāth al-'Arabī,tt), Vol. I, 24.
} 
Menelisik sejarah dan keberagaman corak penafsiran al-Qur'an

ayat qur'āniah, oleh karena itu, dalam al-Qur'an kita temukan ayat-ayat seperti:

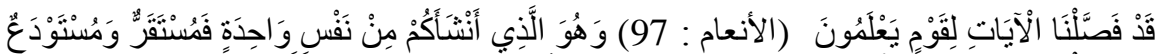

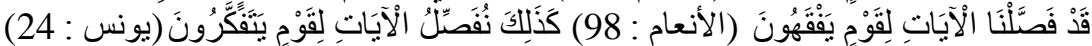

Beberapa ayat di atas mendorong manusia untuk berfikir dan memahami al-Qur'an secara mendalam. Keberadaan ayat yang memiliki ketelitian redaksi mengindikasikan bahwa ayat-ayat seperti ini ditujukan bagi kelompok tertentu yang mampu berfikir secara mendalam. Merekalah yang dibebani untuk menyingkapnya karena hanya mereka yang mampu melakukannya, sebagaimana hanya ahli Baläghah-lah yang dapat mengungkap keindahan bahasa al-Qur'an.

Dengan semangat ini, bermunculan mufasir yang menafsirkan ayatayat kauniah dengan bertolak dari proposisi pokok-pokok bahasa, berdasarkan kapasitas keilmuan yang mereka miliki dan hasil pemikiran dan pengamatan langsung terhadap fenomena-fenomena alam. Menurut Muhammad Shahrür, sebagaimana dikutip oleh Abdul Mustaqim, untuk memahami ayat-ayat al-Qur'an yang berisi informasi ilmu pengetahuan diperlukan “ta'wil 'ilm $\vec{i}$ ( (penafsiran secara ilmiah). Dengan demikian, posisi Nabi Muhammad SAW. sebagai Nabi sebenarnya belum melakukan takwil terhadap ayat-ayat al-Qur'an yang berisi informasi ilmu pengetahuan tersebut. Nabi hanya diberi tugas untuk menyampaikannya kepada manusia tanpa menakwilkannya. Kalaupun Nabi melakukan takwil, maka takwil itu merupakan sesuatu yang nisbi $\bar{i}$, sesuai dengan konteks zamannya. ${ }^{19}$

Berangkat dari paradigma ini, penakwilan terhadap al-Qur'an harus dilakukan secara terus menerus sesuai perkembangan dan kemajuan zaman dan ilmu pengetahuan. Asumsi ini berlandaskan pada konsep thabăt alnash wa taghayyur al-muhtawā (bahwa teks al-Qur'an itu tetap, sedangkan pemahaman mengenai kandungannya bersifat dinamis). Masih menurut Shahrür, dengan melakukan takwil, seseorang akan dapat membuktikan kemu'jizatan al-Qur'an, tidak saja dari aspek linguistic atau keindahan bahasa, akan tetapi juga dari aspek saintifik dan sisi keilmiahannya. Hal ini karena al-Qur'an tidak hanya untuk orang Arab, melainkan untuk seluruh manusia. ${ }^{20}$

Hanya saja, perlu digarisbawahi, bahwa meskipun ayat-ayat alQur'an bisa ditakwil oleh manusia, namun yang dapat menakwilkan secara

\footnotetext{
${ }^{19}$ Mustaqim, Pergeseran Epistemologi Tafsir, (Jakarta, Pustaka Pelajar, 2008), 128

${ }^{20}$ Abdul Mustaqim, Pergeseran Epistemologi Tafsir, (Jakarta, Pustaka Pelajar, 2008), 128
} 
Menelisik sejarah dan keberagaman corak penafsiran al-Qur'an

sempurna hanyalah Allah, sebab pengetahuan Allah bersifat sempurna dan mutlak, sedangkan hasil takwil yang dilakukan oleh manusia bersifat relatif, karena pengetahuan manusia juga bersifat nisbi. Sebagai konsekuensinya, takwil harus bersifat "sairürah" (on going process) berkembang terus-menerus seiring kemajuan dan perkembangan teori ilmu pengetahuan. ${ }^{21}$

Tokoh yang dipercayai gigih dalam mendukung tafsir 'ilm $\bar{i}$ adalah al-Ghazā̄i (w: $1111 \mathrm{M}$ ). Dalam dua kitabnya, yaitu Ihyā', 'Ulūm al-Dīn dan Jawāhir al-Qur'ān ia banyak mengemukakan pendapatnya beserta alasan-alasan yang mendukung. ${ }^{22}$ Al-Ghazāil juga mengatakan: "Segala macam ilmu pengetahuan, baik yang terdahulu maupun yang kemudian, baik yang telah diketahui maupun belum, semua bersumber dari al-Qur'an al-Karim". ${ }^{23}$ Hal ini menurut al-Ghazāli, karena segala macam ilmu termasuk dalam af'āl Allah dan sifat-sifat-Nya, sedangkan al-Qur'an menjelaskan tentang Zat, af'āl, dan sifat-Nya. Pengetahuan tersebut tidak terbatas, dan di dalam al-Qur'an terdapat isarat-isarat menyangkut prinsip-prinsip pokoknya. ${ }^{24}$ Hal terakhir ini, antara lain, dibuktikan dengan mengemukakan ayat, "Apabila aku sakit maka Dia-lah yang mengobatiku" (QS. Ash-Shu 'arā' [26]: 80). Obat dan penyakit, menurut al-Ghazāli tidak dapat diketahui kecuali oleh orang yang berkecimpung di bidang kedokteran. Dengan demikian, ayat di atas merupakan isyarat tentang ilmu kedokteran. ${ }^{25}$

Ulama lain adalah Fakhruddin al-Rāzì, (1209 M), meskipun ia tidak sepenuhnya sependapat dengan al-Ghazāli, namun dalam kitabnya, Mafatih al-Ghaib, ia banyak melakukan pembahasan ilmiah menyangkut filsafat, teologi, ilmu alam, astronomi, kedokteran, dan sebagainya. Sampai-sampai, kitab tafsirnya tersebut dinilai secara berlebihan sebagai mengandung segala sesuatu kecuali tafsir. ${ }^{26}$

Tokoh lainnya adalah Ṭantāwī Jauhari (1870-1940) dalam karyanya Tafsīir al-Jawāhir, bahkan sebelumnya, Muhammad Rashīd Rị̣ā (18651935) dengan Tafsir al-Manār-nya, dinilai berusaha juga membuktikan hal tersebut. Menurut penilaian Ignaz Goldziher, ia berusaha membuktikan bahwa al-Qur'an mencakup segala hakikat ilmiah yang diungkapkan oleh

\footnotetext{
${ }^{21}$ Syahrūr, al-Kitāa wa al-Qur'ān ; Qirā'ah Mu'așirah, (Damaskus: al-Ahāri li al-Ṭibā'ah al-Nashr wa al-Tauzi', 1992), 60.

${ }^{22}$ Quraish Syihab, Membumikan al-Qur'an (Bandung: PT. Mizan Pustaka, 2007), 154.

${ }^{23}$ Al-Ghazā̄i, Ihyā 'Ulūm al-Dīn, (Kairo, al-Thaqāfah al-Islāmiyah,1356 H), Vol.I, 301.

${ }^{24}$ Al-Ghazāili, Jawāhir al-Qur'ān, (Mesir, Percetaka Kurdistan,tt), 31-32.

${ }^{25}$ Quraish Syihab, Membumikan al-Qur'an, (Bandung: PT. Mizan Pustaka, 2007), 155.

${ }^{26}$ Ibid.
} 
Menelisik sejarah dan keberagaman corak penafsiran al-Qur'an

pendapat-pendapat kontemporer (pada masanya), khusunya di bidang filsafat dan sosiologi. ${ }^{27}$

Di lain sisi, al-Shạtibì (w: 1388) merupakan tokoh yang gigih menentang sikap di atas, ia mengatakan, al-Qur'an tidak diturunkan untuk maksud tersebut. ${ }^{28}$ Dan bahwa seseorang dalam rangka memahami alQur'an, harus membatasi diri menggunakan ilmu-ilmu bantu pada ilmuilmu yang dikenal oleh masyarakat Arab pada masa turunnya al-Qur'an, siapa yang berusaha memahaminya dengan menggunakan ilmu-ilmu bantu lainnya, maka ia sesat dan keliru dan mengatasnamakan Allah dan RasulNya dalam hal-hal yang tidak pernah dimaksudkannya. ${ }^{29}$

Namun menurut Quraish Shihab, apa yang dikemukakan oleh alShāțibì di atas, juga sukar untuk dipahami dan diterima, karena kita berkewajiban memahami al-Qur'an sesuai dengan masa sekarang ini sebagaimana wajibnya orang-orang Arab yang hidup di masa dakwah Nabi Muhammad SAW. ${ }^{30}$

Contoh Tafsir ilmi antara lain adalah seperti yang dikutip oleh alDhahabi dalam Tafsir wa al-Mufassirūn.

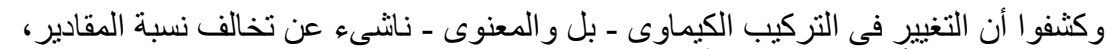

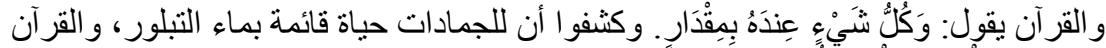

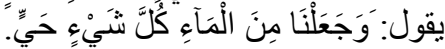

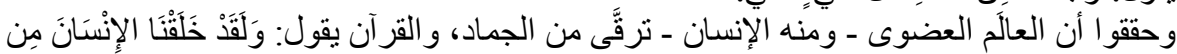

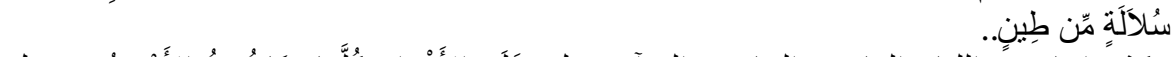

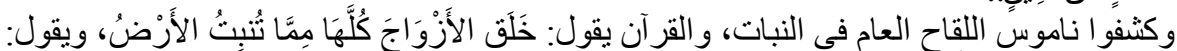

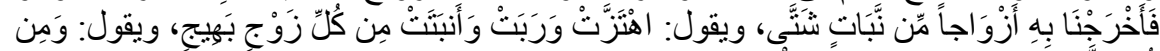

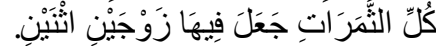

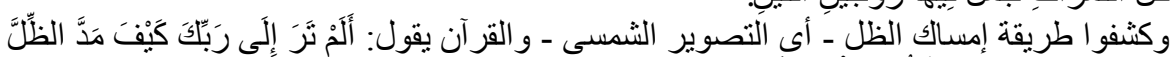

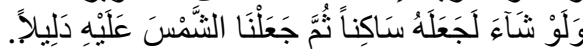

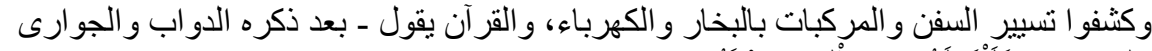

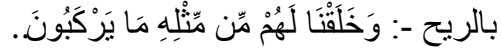

\section{Corak Fiqhỉ}

Sebagaimana corak-corak lain yang mengalami perkembangan dan kemajuan dengan berbagai macam kritik dan pro kontranya, corak fiqhi merupakan corak yang berkembang. Tafsir fiqhỉ lebih popular disebut

\footnotetext{
${ }^{27}$ Ibid.

${ }^{28}$ Al-Shātibīi, al-Muwāfāāàt, ( Beirut : Dār al-Ma'rifah,tt), 80.

${ }^{29}$ Ibid, 81-82.

${ }^{30}$ Quraish Syihab, Membumikan al-Qur'an (Bandung: PT. Mizan Pustaka, 2007), 156.
} 
Menelisik sejarah dan keberagaman corak

penafsiran al-Qur'an

tafsir ayāt al-Ahkām atau tafsir ahkām karena lebih berorientasi pada ayat-ayat hukum dalam al-Qur'an. ${ }^{31}$

Dilihat dari sisi pro-kontranya, tafsir corak fiqhi merupakan jenis corak yang banyak diterima hampir semua lapisan mufasir. ${ }^{32}$ Tafsir ini berusia sudah sangat tua, karena kelahirannya bersamaan dengan kelahiran tafsir al-Qur'an itu sendiri. Banyak sekali judul kitab yang layak untuk disebutkan dalam deretan daftar nama-nama kitab tafsir ayāt al-Ahkām, baik dalam bentuk tahlili maupun maudū'i, antara lain : Ahkām al-Qur'ān karya al-Jașsāạ (917-980 M), seorang faqih madhhab Hanafi. Ahkām alQur'ān karya ibn al-'Arābì (1075-1148 M). al-Jāmi' li ahkām al-Qur'ān karya al-Qurțūbì (w:1272 M). Ahkām al-Qur'ān karya al-Shāfi’’i (w: 204 H.). dan masih banyak lagi karya tafsir di bidang fikih atau Tafsir Ahkām.

Contoh tafsir fiqhi antara lain adalah: kalimat وأرجلكم dalam masalah wudhu' yang terdapat dalam surah al-Māidah ayat 6. Jika dibaca manșub (fathah) maka yang wajib dilakukan pada kaki ketika berwudhu' adalah membasuh bukan mengusap. Akan tetapi jika majrūr (kasrah) maka yang wajib hanya mengusap. ${ }^{33}$

\section{Corak Tasawuf}

Menurut Quraish Shihab, corak ini muncul akibat munculnya gerakan-gerakan sufi sebagai reaksi dari kecenderungan berbagai pihak terhadap materi, atau sebagai kompensasi terhadap kelemahan yang dirasakan. ${ }^{34}$ Di samping karena dua faktor yang dikemukakan oleh Qurais Shihab di atas, faktor lain adalah karena berkembangnya era penerjemahan karya-karya filsafat Yunani di dunia Islam, maka muncul pula tafsir-tafsir sufi falsafí. Antara lain adalah Tafsir al-Qur'ān karya Sahal ibn Abdillah al-Tustāri (w: 283H). Tafsir ini dinilai oleh sebagian orang tidak memuaskan karena tidak lebih dari 200 halaman dan tidak lengkap mengapresiasi al-Qur' an 30 juz. $^{35}$

Kemudian muncul pula Haqāiq al-Tafsìr karya Abū Abdurrahmān al-Sulami (w: 412 H). Namun tafsir ini dinilai oleh Ibnu Salạ dan alDhahabì sebagai tafsir yang banyak mengadung kecacatan, bahkan dituduh banyak bid'ah, berbau shi' 'ah dan banyak memuat hadis maudi ${ }^{, 36}$

\footnotetext{
${ }^{31}$ Ahmad Izzan, Metodologi Ilmu Tafsir, (Bandung: Tafakur,2009), 200.

32 Ibid, 201.

${ }^{33}$ Abū Abdillah al-Qurțūbi, al-Jāmi' li Ahkām al-Qur'ān, (Bairut, Lebanon: Dār al-Kutub al-Arabi, Cet. V, 2003) Jilid. 6 hal. 90

${ }^{34}$ Quraish Syihab, Membumikan al-Qur'an (Bandung: PT. Mizan Pustaka, 2007), 108.

${ }^{35}$ Abdul Mustaqim, Pergeseran Epistemologi Tafsir, (Jakarta: Pustaka Pelajar, 2008), 62.

${ }^{36}$ Ibid.
} 
Menelisik sejarah dan keberagaman corak

penafsiran al-Qur'an

Demikian pula al-Dhahabi dalam kitab Tazkirah al-Huffä pernah berkomentar bahwa kitab Haqāiq al-Tafsìr banyak terdapat takwil kaum bătīini. Ibnu Taimiyah dalam kitab Minhāj al-Sunnah menyatakan bahwa kitab tersebut banyak dusta. ${ }^{37}$

Ada juga pula Latāif al-Ishārāt karya Abd al-Karim ibn Hawāzin ibn Abd al-Mālik ibn Talhah ibn Muhammad al-Qushairi $(374 \mathrm{H}-465 \mathrm{H})$. Kitab ini dinilai positif oleh para ulama karena penafsirannya tidak menyimpang dan selalu berusaha mempertemukan antara dimensi syariat dan hakikat, antara lain makna lahir dan batin. Selain itu, tafsir tersebut relatif steril dari pembelaan ideologi mazhab. ${ }^{38}$

Contoh penafsiran corak tasawuf atau süfí antara lain adalah penafsiran al-Qushairi pada ayat:

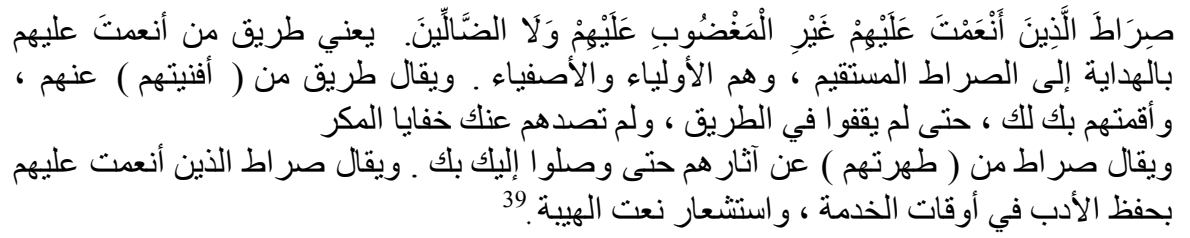

\section{Corak al-Adabī wa al-Ijtimā '̄i}

al-Adabī wa al-Ijtimā'i terdiri dari dua kata, yaitu al-Adabi dan alIjtimā'î. Corak tafsir yang memadukan filologi dan sastra (tafsir adabî́), dan corak tafsir kemasyarakatan. Corak tafsir kemasyarakatan ini sering dinamakan juga ijtima $\bar{i}$. Kata al-Adabi dilihat dari bentuknya termasuk mașdar (infinitif) dari kata kerja (maḍi) aduba, yang berarti sopan santun, tata krama dan sastra.

Secara leksikal, kata tersebut bermakna norma-norma yang dijadikan pegangan bagi seseorang dalam bertingkah laku dalam kehidupannya dan dalam mengungkapkan karya seninya. Oleh karena itu, istilah al-adabi $\vec{i}$ bisa diterjemahkan sastra budaya. Sedangkan kata alIjtima $\bar{T} \bar{i}$ bermakna banyak bergaul dengan masyarakat atau bisa diterjemahkan kemasyarakatan atau sosial. Jadi secara etimologis tafsir alAdabi al-Ijtima $\bar{a} \bar{i}$ adalah tafsir yang berorientasi pada satra budaya dan kemasyarakatan, atau bisa disebut dengan tafsir sosio-kultural. ${ }^{40}$

\footnotetext{
${ }^{37}$ Ibid.

${ }^{38}$ Ibid.

${ }^{39}$ Al-Qusyairi, Latāif al-Ishārāt, (Beirut: Dār al-Kutub al-Ilmiah, 2007), Vol.I, 14.

${ }^{40}$ M. Karman Supiana, Ulumul Qur'an (Bandung: PUSTAKA ISLAMIKA, 2002), 316317.
} 
Menelisik sejarah dan keberagaman corak penafsiran al-Qur'an

Kepopuleran corak ini dimulai pada masa Shaikh Muhammad Abduh (1849-1905). ${ }^{41}$ Corak tafsir al-Adabi al-Ijtimā $\bar{i}$ adalah corak tafsir yang menjelaskan petunjuk-petunjuk ayat-ayat al-Qur'an yang berkaitan langsung dengan masyarakat, serta usaha-usaha untuk menanggulangi penyakit-penyakit masyarakat atau masalah-masalah mereka berdasarkan petunjuk ayat-ayat, dengan mengemukakan petunjuk-petunjuk tersebut dalam bahasa yang mudah dimengerti tapi indah didengar. ${ }^{42}$

Jadi, corak penafsiran al-Adabí al-Ijtima $\bar{i} \bar{i}$ adalah corak penafsiran yang berorientasi pada sastra budaya kemasyarakatan. Suatu corak penafsiran yang menitikberatkan penjelasan ayat al-Qur' an pada segi-segi ketelitian redaksionalnya, kemudian menyusun kandungan ayat-ayatnya dalam suatu redaksi yang indah dengan penonjolan tujuan utama turunnya ayat, kemudian merangkaikan pengertian ayat tersebut dengan hukumhukum alam yang berlaku dalam masyarakat dan pembangunan dunia.

Contoh Tafsir Adabí Ijtimā $\bar{i}$ antara lain adalah mengenai masalah sosial, sebagaimana dikutip oleh al-Dhahabi dalam al-Tafsir wa alMufassirūn :

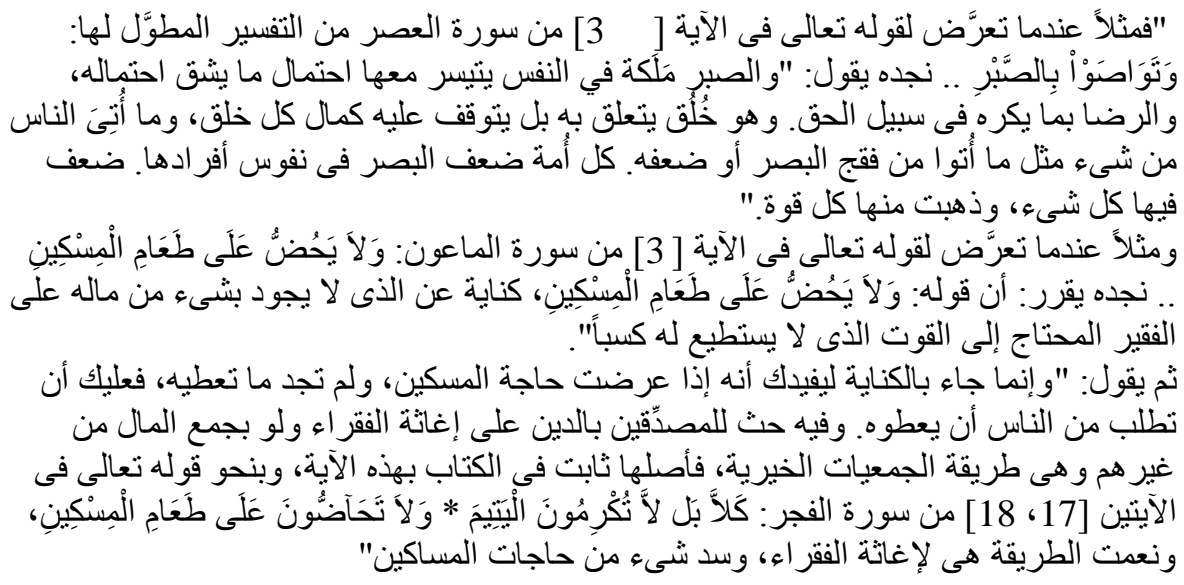

\section{Epilog}

Corak tafsir diartikan sebagai kecenderungan atau spesifikasi seorang mufasir dalam menafsirkan al-Qur'an. Hal ini tentu dilatarbelakangi oleh pendidikan, lingkungan dan akidahnya.

Pada abad pertengahan, berbagai corak ideologi penafsiran mulai lahir, lahirnya berbagai ideologi inilah yang menjadi embrio keberagaman

\footnotetext{
${ }^{41}$ Quraish Syihab, Membumikan al-Qur'an (Bandung: PT. Mizan Pustaka, 2007), 108.

42 Ibid.
} 
Menelisik sejarah dan keberagaman corak

penafsiran al-Qur'an

corak dalam penafsiran al-Qur'an. Fase ini dimulai pada masa akhir dinasti Umayyah dan awal dinasti bani Abbāsiyah. Hal ini terutama ketika masa pemerintahan khalifah kelima Dinasti Abbasiyah, yaitu Hārūn alRasyid (785-809 M). dilanjutkan oleh khalifah berikutnya yaitu alMakmūn (813-830 M).

Corak tafsir yang muncul dan berkembang pada masa itu dan masamasa sesudahnya antara lain, corak lughawi, corak filsafat, corak'ilmi, corak fiqhi, corak tasawuf dan corak adabỉ ijtima $\hat{i}$.

\section{Daftar Pustaka}

Anwar, Rosihon, Ilmu Tafsir, Bandung: Pustaka Setia, 2008.

Ghazāli (al), Muhammad ibn Muhammad, Jawāhir al-Qur'ān, Mesir: Percetaka Kurdistan, tt.

----------, Ihyā 'Ulūm al-Dīn, Kairo: al-Thaqāfah al-Islāmiyah, $1356 \mathrm{H}$.

Izzan, Ahmad, Metodologi Ilmu Tafsir, Bandung: Tafakur,2009.

Karman, Supiana-M., Ulumul Qur'an Bandung: Pustaka Islamika, 2002.

LAL, Anshori, Tafsir bi al-Ra'yi, Menafsirkan al-Qur'an Dengan Ijtihad, Jakarta: Gaung Persada Press, 2010.

Maḥalli, (al) dan al-Suyūțī, Tafsir al-Jalālain,tp., tt.

Manzūur, Muhammad bin Mukram ibn , Lisān al-'Arab. Beirut: Dār Shādir, $1412 \mathrm{H}$

Munawwir, Ahmad Warson, Kamus Al-Munawwir, Yogyakarta: Pustaka Progressif, 1997.

Mustaqim, Abdul, Pergeseran Epistemologi Tafsir, Jakarta: Pustaka Pelajar, 2008.

Qurțubī (al), Abū Abdillah, al-Jāmi' li Ahkām al-Qur'ān, Bairut: Libanon: Dār al-Kutub al-Arabi, Cet. V, 2003.

Qushairì (al), Latäif al-Ishārät, (Beirut: Dār al-Kutub al-Ilmiah, 2007).

Rāzi (al), Mafătih al-Ghaib, (Beirut: Dār Ihyā' al-Turāth al-'Arabì, tt).

Shahrūr, Muhammad, al-Kitāb wa al-Qur'ān; Qirā'ah Mu'asirah, Damaskus: al-Ahāli li al-Ṭibā'ah al-Nashr wa al-Tauzi'‘, 1992.

Shāțibī (al), al-Muwāfāqāt, Beirut : Dār al-Ma'rifah, tt.

Shurbasi, Ahmad, Sejarah Perkembangan Tafsir al-Qur'an al-Karim, Jakarta: Kalam Mulia, Cet. I, 1999.

Shihab, M. Quraish, Membumikan al-Qur'an, Bandung: PT. Mizan Pustaka, 2007.

Tim Penyusun Kamus Pusat Bahasa, Kamus Besar Bahasa Indonesia, Jakarta: Balai Pustaka, 2005.

Dhahabì (al), Muhammad Husein, al-Tafsir wa al-Mufassirūn, Maktabah Mus'ab ibn Umar al-Islāmiyah, 2004. 
Menelisik sejarah dan keberagaman corak penafsiran al-Qur'an

Zarkāshī (al), “Al-Burhān fí Ulūm al-Qur'ān”, Dār al-Ahyā al-Kutub alArabiyah, cet I, 1376 H-1957 M. 